\title{
Impact of Simulated Martian Conditions on (Facultatively) Anaerobic Bacterial Strains from Different Mars Analogue Sites
}

Kristina Beblo-Vranesevic ${ }^{1^{*}}$, Maria Bohmeier ${ }^{1}$, Sven Schleumer ${ }^{1,2}$, Elke Rabbow $^{1}$, Alexandra K. Perras ${ }^{3,4}$, Christine MoissI-Eichinger ${ }^{3,7}$, Petra Schwendner ${ }^{5,6}$, Charles S. Cockell ${ }^{5}$, Pauline Vannier ${ }^{8}$, Viggo T. Marteinsson ${ }^{8,9}$, Euan P. Monaghan ${ }^{10}$, Andreas Riedo ${ }^{10}$, Pascale Ehrenfreund $^{10,11}$, Laura Garcia-Descalzo ${ }^{12}$, Felipe Gómez ${ }^{12}$, Moustafa Malki $^{13}$, Ricardo Amils ${ }^{13}$, Frédéric Gaboyer ${ }^{14}$, Keyron Hickman-Lewis ${ }^{14}$, Frances Westall ${ }^{14}$, Patricia Cabezas ${ }^{15}$, Nicolas Walter ${ }^{15}$ and Petra Rettberg ${ }^{1}$

${ }^{1}$ Institute of Aerospace Medicine, Radiation Biology Department, German Aerospace Center (DLR), Cologne, Germany

${ }^{2}$ Hochschule Niederrhein, Wirtschaftingenieurswesen, Krefeld, Germany 3Department of Internal Medicine, Medical University of Graz, Graz, Austria ${ }^{4}$ Department of Microbiology and Archaea, University of Regensburg, Regensburg, Germany 5UK Center for Astrobiology, School of Physics and Astronomy, University of Edinburgh, Edinburgh, UK 'Department of Plant Pathology, Space Life Sciences Laboratory, University of Florida, FL, USA ${ }^{7}$ BioTechMed Graz, Graz, Austria ${ }^{8}$ MATIS - Prokaria, Reykjavík, Iceland

${ }^{9}$ Faculty of Food Science and Nutrition, University of Iceland, Reykjavík, Iceland ${ }^{10}$ Leiden Observatory, Universiteit Leiden, Leiden, Netherland

${ }^{11}$ Space Policy Institute, George Washington University, Washington DC, USA ${ }^{12}$ Instituto Nacional de Técnica Aeroespacial - Centro de Astrobiología (INTA-

CAB), Madrid, Spain

${ }^{13}$ Centro de Biología Molecular Severo Ochoa, Universidad Autónoma de Madrid (UAM), Madrid, Spain

${ }^{14}$ Centre de Biophysique Moléculaire, Centre National de la Recherche Scientifique (CNRS), Orléans, France

${ }^{15}$ European Science Foundation (ESF), Strasbourg, France

*kristina.beblo@dlr.de

DOI: https://doi.org/10.21775/9781912530304.05 


\section{Abstract}

Five bacterial (facultatively) anaerobic strains, namely Buttiauxella $\mathrm{sp}$. MASE-IM-9, Clostridium sp. MASE-IM-4, Halanaerobium sp. MASE-BB-1, Trichococcus sp. MASE-IM-5, and Yersinia intermedia MASE-LG-1 isolated from different extreme natural environments were subjected to Mars relevant environmental stress factors in the laboratory under controlled conditions. These stress factors encompassed low water activity, oxidizing compounds, and ionizing radiation. Stress tests were performed under permanently anoxic conditions. The survival rate after addition of sodium perchlorate (Na-perchlorate) was found to be species-specific. The intercomparison of the five microorganisms revealed that Clostridium $\mathrm{sp}$. MASE-IM-4 was the most sensitive strain $\left(\mathrm{D}_{10}\right.$-value $\left(15 \mathrm{~min}, \mathrm{NaClO}_{4}\right)=$ $0.6 \mathrm{M})$. The most tolerant microorganism was Trichococcus sp. MASE-IM-5 with a calculated $\mathrm{D}_{10}$-value $\left(15 \mathrm{~min}, \mathrm{NaClO}_{4}\right)$ of $1.9 \mathrm{M}$. Cultivation in the presence of Na-perchlorate in Martian relevant concentrations up to $1 \mathrm{wt} \%$ led to the observation of chains of cells in all strains. Exposure to $\mathrm{Na}$ perchlorate led to a lowering of the survival rate after desiccation. Consecutive exposure to desiccating conditions and ionizing radiation led to additive effects. Moreover, in a desiccated state, an enhanced radiation tolerance could be observed for the strains Clostridium sp. MASE-IM-4 and Trichococcus sp. MASE-IM-5. These data show that anaerobic microorganisms from Mars analogue environments can resist a variety of Martian-simulated stresses either individually or in combination. However, responses were species-specific and some Mars-simulated extremes killed certain organisms. Thus, although Martian stresses would be expected to act differentially on microorganisms, none of the expected extremes tested here and found on Mars prevent the growth of anaerobic microorganisms.

\section{Introduction}

Mars has been a favored target in the search of extinct or extant life beyond the Earth. Various articles have been published discussing the habitability of early and present-day Mars (e.g. Tosca et al., 2008; Westall et al., 2013; Cockell et al., 2016; Eigenbrode et al., 2018). The present-day Martian surface is characterized by the absence of liquid water. If there is liquid water in the near-surface environment it likely occurs temporarily as brines (Orosei et al., 2018), i.e. with high concentrations of different salts, including perchlorates. In addition, the Martian surface is exposed to a high radiation flux in form of ionizing radiation and solar UV-radiation due to a thin anoxic atmosphere consisting of mainly $\mathrm{CO}_{2}$, and by the lack of a planetary magnetic field (Horneck, 2000, Jakosky et al., 2001, MartinTorres et al., 2015, McEwen et al., 2011, Hassler et al., 2014, Matthiä et al., 2016, Schubert et al., 2000, Gu et al., 2018).

Another potentially harmful environmental factor on the Martian surface is the ubiquitous presence of oxidizing compounds, especially perchlorates, which might have a strong impact on habitability. The Phoenix lander detected significant concentrations up to 0.6 weight percent $(w t \%)$ of 
perchlorate ions at the landing site in the northern polar regions (Hecht et al., 2009). The MSL mission showed that perchlorates are present presumably on the entire surface of Mars (Archer et al., 2013). At distinct places different types of perchlorates have been detected. For example, a mixture of sodium perchlorate (Na-perchlorate) and magnesium perchlorate (Mg-perchlorate) were inferred in the Palikir and Hale crater. At Horowitz crater Na-perchlorate has been suggested and at Gale Crater calcium-perchlorate was inferred (Ojha et al., 2015; Glavin et al., 2013). The detailed formation mechanism of perchlorates is still not fully understood. Two different formation mechanisms of Martian perchlorates have been suggested. One hypothesis suggests that the perchlorates were produced on the surface whereby Martian surface minerals catalyze the photochemical oxidation of chlorides to perchlorates (Schuttlefield et al., 2011; Kim et al., 2013). It was shown that in chloride-containing Martian soil simulants, perchlorates are produced in the presence of ultraviolet light (Carrier and Kounaves, 2015). Another formation mechanism might be through the reaction of atmospheric oxidants probably on dust particles in the arid environment on Mars (Catling et al., 2010). Perchlorates, as hygroscopic substances, bind water from the atmosphere and contribute to the formation of brines with high concentrations of different dissolved salts, including chlorides, sulfates, and perchlorates. In some regions these brines are thought to remain liquid even at the low temperatures prevailing on the surface of Mars (Gough et al., 2011; Toner and Catling, 2016; Kounaves et al., 2014; Fox-Powell et al., 2016; Martín-Torres et al., 2015).

The working program of the European Community's Seventh Framework Program project MASE (Mars analogues for space exploration; grant agreement $n^{\circ}$ 607297) included sampling from terrestrial Mars analogue sites to obtain new (facultatively) anaerobic model microorganisms adapted to extreme conditions (Cockell et al., 2017). In this study, some of these microorganisms were exposed to a representative subset of environmental conditions as they occur on present-day Mars. They were perchlorates at different concentrations, absence of water, ionizing radiation, and a Martian atmosphere pressure. As these are some of the most prominent stress factors in a Martian environment, the biological effects on the microorganisms where examined when exposed to individual stress factors and in combination.

\section{Material and Methods}

\section{Strains and culture conditions}

In order to get an impression of the natural distribution of tolerances to simulated Martian conditions, only the wild type organisms were used. These strains were obtained in the context of the MASE project from various extreme environments which were considered Mars analogues sites (Cockell et al., 2017). The following microorganisms were investigated: Buttiauxella sp. MASE-IM-9 (DSM 105071), Clostridium sp. MASE-IM-4 (DSM 105631), Halanaerobium sp. MASE-BB-1 (DSM 
Table 1. Strains, origin and cultivation conditions. ${ }^{a}$ at the applied cultivation conditions, no spores of Clostridium sp. MASE-IM-4 were detectable.

\begin{tabular}{|c|c|c|c|c|c|}
\hline Strain & Origin & Medium & $\begin{array}{l}\text { Supplements in } \\
\text { MASE medium (wt\%) }\end{array}$ & $\begin{array}{l}\text { Gas } \\
\text { phase } \\
\text { (vol\%) }\end{array}$ & $\begin{array}{l}\text { Temp. } \\
\left({ }^{\circ} \mathrm{C}\right)\end{array}$ \\
\hline $\begin{array}{l}\text { Buttiauxella sp. } \\
\text { MASE-IM-9 }\end{array}$ & $\begin{array}{l}\text { Islinger } \\
\text { Mühlbach, } \\
\text { Germany }\end{array}$ & $\begin{array}{l}\text { MASE-II / } \\
\text { TSA }\end{array}$ & $0.1 \%$ Yeast extract & $\begin{array}{l}80 \% \mathrm{~N}_{2} \\
20 \% \mathrm{CO}_{2}\end{array}$ & 30 \\
\hline $\begin{array}{l}\text { Clostridium sp. } \\
\text { MASE-IM-4a }^{\text {MAS }}\end{array}$ & $\begin{array}{l}\text { Islinger } \\
\text { Mühlbach, } \\
\text { Germany }\end{array}$ & $\begin{array}{l}\text { MASE-II } \\
-\mathrm{FeCl}_{2} / \\
\text { TSA }\end{array}$ & $\begin{array}{l}0.01 \% \text { Dimethylamine } \\
0.001 \% \mathrm{FeCl}_{2}\end{array}$ & $\begin{array}{l}15 \% \mathrm{H}_{2}, \\
25 \% \mathrm{CO}_{2}, \\
60 \% \mathrm{~N}_{2}\end{array}$ & 30 \\
\hline $\begin{array}{l}\text { Halanaerobium sp. } \\
\text { MASE-BB-1 }\end{array}$ & $\begin{array}{l}\text { Boulby Mine, } \\
\text { Great Britain }\end{array}$ & $\begin{array}{l}\text { HACE. No } \\
\text { growth on } \\
\text { solid } \\
\text { surfaces. }\end{array}$ & $0.1 \%$ Yeast extract & $\begin{array}{l}15 \% \mathrm{H}_{2}, \\
25 \% \mathrm{CO}_{2}, \\
60 \% \mathrm{~N}_{2}\end{array}$ & 45 \\
\hline $\begin{array}{l}\text { Trichococcus sp. } \\
\text { MASE-IM-5 }\end{array}$ & $\begin{array}{l}\text { Islinger } \\
\text { Mühlbach, } \\
\text { Germany }\end{array}$ & $\begin{array}{l}\text { MASE-II } \\
-\mathrm{FeCl}_{2} / \\
\text { TSA }\end{array}$ & $\begin{array}{l}0.01 \% \mathrm{Na}_{2} \mathrm{SO}_{4} \\
0.01 \% \mathrm{C}_{6} \mathrm{H}_{5} \mathrm{Na}_{3} \mathrm{O}_{7} \mathrm{x} \\
2 \mathrm{H}_{2} \mathrm{O} \\
0.02 \% \mathrm{KNO}_{3}\end{array}$ & $\begin{array}{l}15 \% \mathrm{H}_{2}, \\
25 \% \mathrm{CO}_{2}, \\
60 \% \mathrm{~N}_{2}\end{array}$ & 30 \\
\hline $\begin{array}{l}\text { Yersinia intermedia } \\
\text { MASE-LG-1 }\end{array}$ & $\begin{array}{l}\text { Lake Grænavatn, } \\
\text { Iceland }\end{array}$ & $\begin{array}{l}\text { MASE-I / } \\
\text { TSA }\end{array}$ & $\begin{array}{l}0.01 \% \mathrm{KNO}_{3} \\
0.01 \% \mathrm{C}-\text { Org-Mix }\end{array}$ & $\begin{array}{l}80 \% \mathrm{~N}_{2} \\
20 \% \mathrm{CO}_{2}\end{array}$ & 30 \\
\hline
\end{tabular}

105537), Trichococcus sp. IM-5 (DSM 105632), and Yersinia intermedia MASE-LG-1 (DSM 102845). Medium compositions and strain-specific anoxic cultivation conditions are summarized in Table 1 and described in detail by Cockell et al. (2017). The incubation was carried out at the indicated cultivation temperature and cultures were shaken at $50 \mathrm{rpm}$.

Individual and combined stress tests

All stress tests were performed in anoxic MASE/HACE medium (Table 1). The influence of individual and combined stress factors on the selected MASE isolates were examined (Table 2).

Table 2. Overview of performed individual and combined stress tests with the MASE-strains.

\begin{tabular}{|l|l|}
\hline Individual stress & Conditions \\
\hline Na-perchlorate exposure & 15 minutes, 4 hours, 24 hours 96 hours; $\leq 4 \mathrm{M}$ \\
\hline Growth in the presence of Na-perchlorate & $0.5 \mathrm{wt} \%$ / 1 wt \%, 24 hours \\
\hline Combined Stress & Conditions \\
\hline Na-perchlorate addition and desiccation & $0.5 \mathrm{wt} \%$ / 1 wt $\%$; 4 hours \\
\hline Desiccation and X-rays & 24 hours; $\leq 3000$ Gy \\
\hline Desiccation and Mars atmosphere & 24 hours; $\leq 1$ month \\
\hline
\end{tabular}


For the investigation of the effect of Na-perchlorate as individual stress factor the cells were exposed to different concentrations of Na-perchlorate up to $4 \mathrm{M}$ including Martian relevant concentrations of $36 \mathrm{mM}(\sim 0.5 \mathrm{wt} \%)$ and $71 \mathrm{mM}(\sim 1.0 \mathrm{wt} \%)$. Na-perchlorate was added to an overnight culture grown at strain-specific optimal conditions. After anoxic incubation up to 96 hours at room temperature, the exposure was terminated by sudden dilution (1:400), followed by the determination of the survival rate by the most probable number technique (MPN) or a plating assay.

In addition to these exposure experiments, the ability of the model organisms to actively grow and multiply in the presence of perchlorates was tested. Martian relevant concentrations of Na-perchlorate $(0.5 \mathrm{wt} \%$ or $1.0 \mathrm{wt} \%$ ) were added before inoculation and cultivation was conducted at optimal growth conditions in the presence of Na-perchlorate.

For experiments using desiccation as an individual stress factor as well as in combination with other stresses, i.e. desiccation and exposure to radiation or exposure to Martian atmosphere, (see also Table 2), the cells were cultivated under optimal growth conditions until stationary growth phase was reached $(\sim 24 \mathrm{~h})$. Desiccation experiments were performed as described earlier (Beblo et al., 2009). One milliliter of culture (equivalent to $\sim 10^{7}$ cells) was spread evenly on sterile glass slides or quartz discs and dried under anoxic conditions within an anaerobic chamber (Coy Laboratory Products Inc.; $\left[\mathrm{O}_{2}\right]<5 \mathrm{ppm}$, relative humidity $13 \pm 0.5 \mathrm{vol} \%$ ). Perchlorate treated cells were desiccated in an identical way.

Exposure to ionizing radiation, in the form of X-rays, was performed as described in earlier studies with the X-ray source Gulmay RS 225A (Gulmay Medical Ltd.) at $200 \mathrm{kV}$ and $15 \mathrm{~mA}$ (Beblo et al., 2011). The cells were irradiated at a distance of $19.5 \mathrm{~cm}$ below the X-ray source with $20 \mathrm{~Gy} /$ $\min \pm 5 \mathrm{~Gy} / \mathrm{min}$ up to $3000 \mathrm{~Gy}$. The dose rate was measured with a UNIDOS dosimeter (PTW Freiburg $\mathrm{GmbH}$ ). All irradiation experiments were performed at room temperature.

The combination of anoxic desiccation and ionizing irradiation and the combination of anoxic desiccation and exposure to a simulated Martian atmosphere (a Mars-like gas composition (2.7 vol\% N $2,1.6$ vol\% $\mathrm{Ar}, 0.15$ vol\% $\mathrm{O}_{2}$ in $\mathrm{CO}_{2}$ ) at a pressure of $10^{3} \mathrm{~Pa}$ ), were carried out using the previously described TRex-Box (Beblo-Vranesevic et al., 2017a).

If not stated otherwise all exposures and treatments were performed under anoxic conditions at room temperature.

Determination of survival rate

Growth and morphology of the unfixed native cells was observed by phasecontrast light microscopy (ZeissR AxiolmagerTM M2) with $400 \times$ or $1000 \times$ magnification. 
Determination of the survival rate and enumeration of cultivable cells was achieved by the MPN-technique via dilution series with ten-fold dilution steps in anoxic MASE/HACE medium (Franson, 1985). The cells were incubated at their optimal growth temperature for up to four weeks. Alternatively, the survival rate was determined by applying a plating assay on tryptic soy agar (TSA) plates under anoxic conditions for Buttiauxella sp. MASE-IM-9, Clostridium sp. MASE.IM-4, Trichococcus sp. MASE-IM-5, Yersinia intermedia MASE-LG-1 (see also Table 1). The plates were incubated in an anaerobic chamber at room temperature up to one week. All experiments were repeated independently at least three times to represent biological replicas.

\section{Results}

Survival of MASE-strains after exposure to perchlorates as individual stress factor

To get an overview of the tolerance of the MASE-strains towards $\mathrm{Na}$ perchlorate, survival curves after 15 minutes exposure and the corresponding calculation of the $\mathrm{D}_{10}$-values were performed as shown in Figure 1 and Table 3 . All tested strains survived the treatment with $\mathrm{Na}$ perchlorate as an individual stress factor for 15 minutes at room temperature.

Table 3. Calculated $D_{10}$-values of MASE-strains after addition of Na-perchlorate for 15 minutes at room temperature.

* data from Beblo-Vranesevic et al. 2017b.

\begin{tabular}{|l|l|}
\hline Strain & $\mathbf{D}_{10}$-value [M] $\mathrm{NaCIO}_{4}$ \\
\hline Clostridium sp. MASE-IM-4 & 0.6 \\
\hline Buttiauxella sp. MASE-IM-9 & 1.2 \\
\hline Halanaerobium sp. MASE-BB-1 & 1.5 \\
\hline Yersinia intermedia MASE-LG-1 & 1.7 \\
\hline Trichococcus sp. MASE-IM-5 & 1.9 \\
\hline \multicolumn{2}{|l}{} \\
\hline Escherichia coli & $1.3^{*}$ \\
\hline Bacillus subtilis (vegetative cells) & $1.9^{*}$ \\
\hline Deinococcus radiodurans & $2.7^{*}$ \\
\hline
\end{tabular}




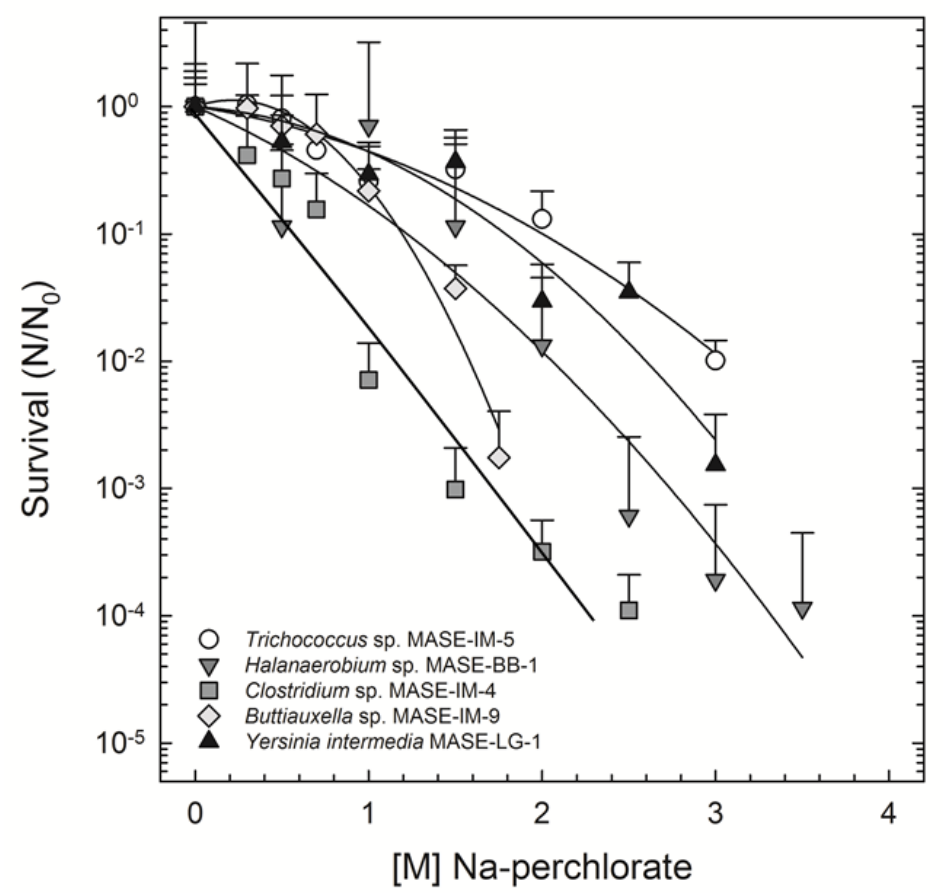

Figure 1. Survival after 15 minutes anoxic exposure to Na-perchlorate. $\mathrm{N}_{0}$ : viable non-treated cells; $\mathrm{N}$ : viable cells after exposure to Na-perchlorate for 15 minutes $(n=3)$. Error bars are representing the standard deviation.

The MASE-strains were ranked in terms of their tolerance to $\mathrm{Na}$ perchlorate after an exposure for 15 minutes in the following descending order from tolerant to sensitive: Trichococcus sp. MASE-IM-5 > Yersinia intermedia MASE-LG-1 > Halanaerobium sp. MASE-BB-1 > Buttiauxella sp. MASE-IM-9 > Clostridium sp. MASE-IM-4. This is also visible in the calculated $D_{10}$-values of the investigated MASE-strains ranking from $0.6 \mathrm{M}$ to $1.9 \mathrm{M}$ (15 min, $\left.\mathrm{NaClO}_{4}\right)$ (Table 3).

It could be shown that exposure to lower concentrations of Na-perchlorate (36 $\mathrm{mM}=0.5 \mathrm{wt} \%$ and $71 \mathrm{mM}=1.0 \mathrm{wt} \%$ ), equivalent to concentrations occurring on Mars, for up to 96 hours at room temperature under anoxic conditions did not lead to an alteration in survivability of all five MASEstrains. The number of living cells remained the same or it was elevated due to further growth at room temperature for the tested time period of up to 96 hours (Figure 2). 


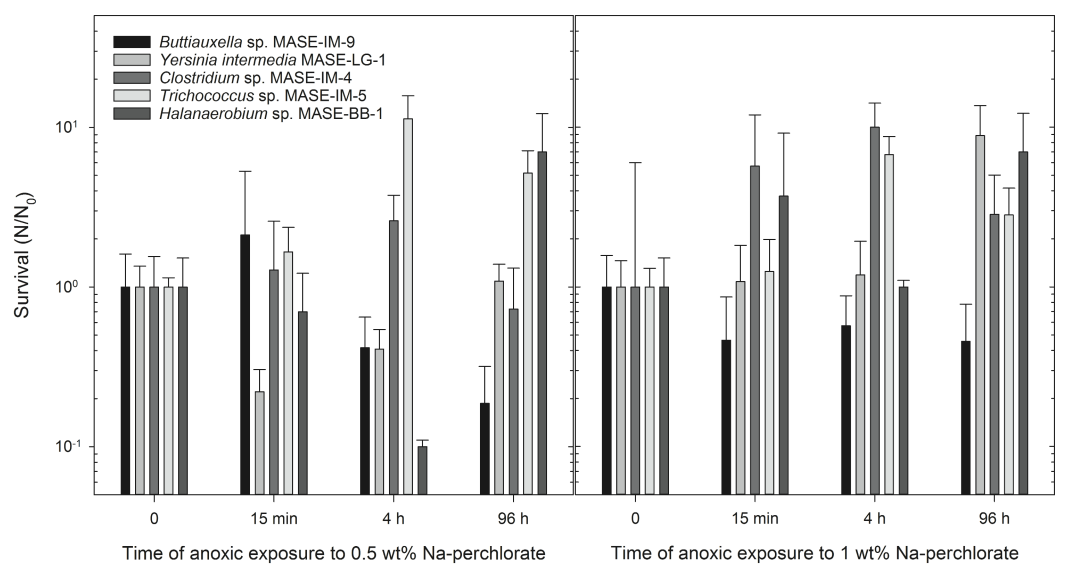

Figure 2. Response of organisms to Na-perchlorate. MASE-strain cultures (Buttiauxella sp. MASEIM-9, Yersinia intermedia MASE-LG-1, Clostridium sp. MASE-IM-4, Trichococcus sp. MASE-IM-5, Halanaerobium sp. MASE-BB-1) were incubated in the presence of Na-perchlorate under anoxic conditions at room temperature. $\mathrm{N}$ : Viable cells without added perchlorate, $\mathrm{N}$ : Viable cells after storage in the presence of perchlorates (0.5 wt $\%$ or $1.0 \mathrm{wt} \%$ ). Recovery was performed under standard cultivation conditions without perchlorate $(n=3)$. Error bars are representing the standard deviation.

\section{Growth in the presence of perchlorate}

Despite the fact that all MASE-strains were growing mainly as single cells under standard cultivation conditions, microscopically observations revealed that all strains showed extensive cell agglomerations (i.e. cell-cellconnections) with increasing $\mathrm{Na}$-perchlorate concentrations if perchlorate was present during cultivation (Figure 3). Buttiauxella sp. MASE-IM-9, Clostridium sp. IM-5, Halanaerobium sp. MASE-BB-1, and Yersinia intermedia MASE-LG-1 showed chain formation of increasing length in the presence of Na-perchlorate. The longest cell-chains were observed for Halanaerobium sp. MASE-BB-1 and Buttiauxella sp. MASE-IM-9. Yersinia intermedia MASE-LG-1 and Clostridium sp. MASE-IM-4 showed additionally an elongation of the cells itself if they were growing in chains. Trichococcus sp. MASE-IM-5, normally growing as diplo-coccus or three to four cells attached together, formed chains like pearls on a string.

\section{Perchlorates and desiccation - combined stresses}

The exposure to Martian concentrations of Na-perchlorate and subsequent desiccation showed additive effects of both stresses with regard to survivability. Na-perchlorate had a negative influence on the desiccation tolerance of all tested organisms (Figure 4). In the presence of Naperchlorate, the survival rate was lowered up to five orders of magnitude compared to desiccation for 24 hours without perchlorates. The lowest 

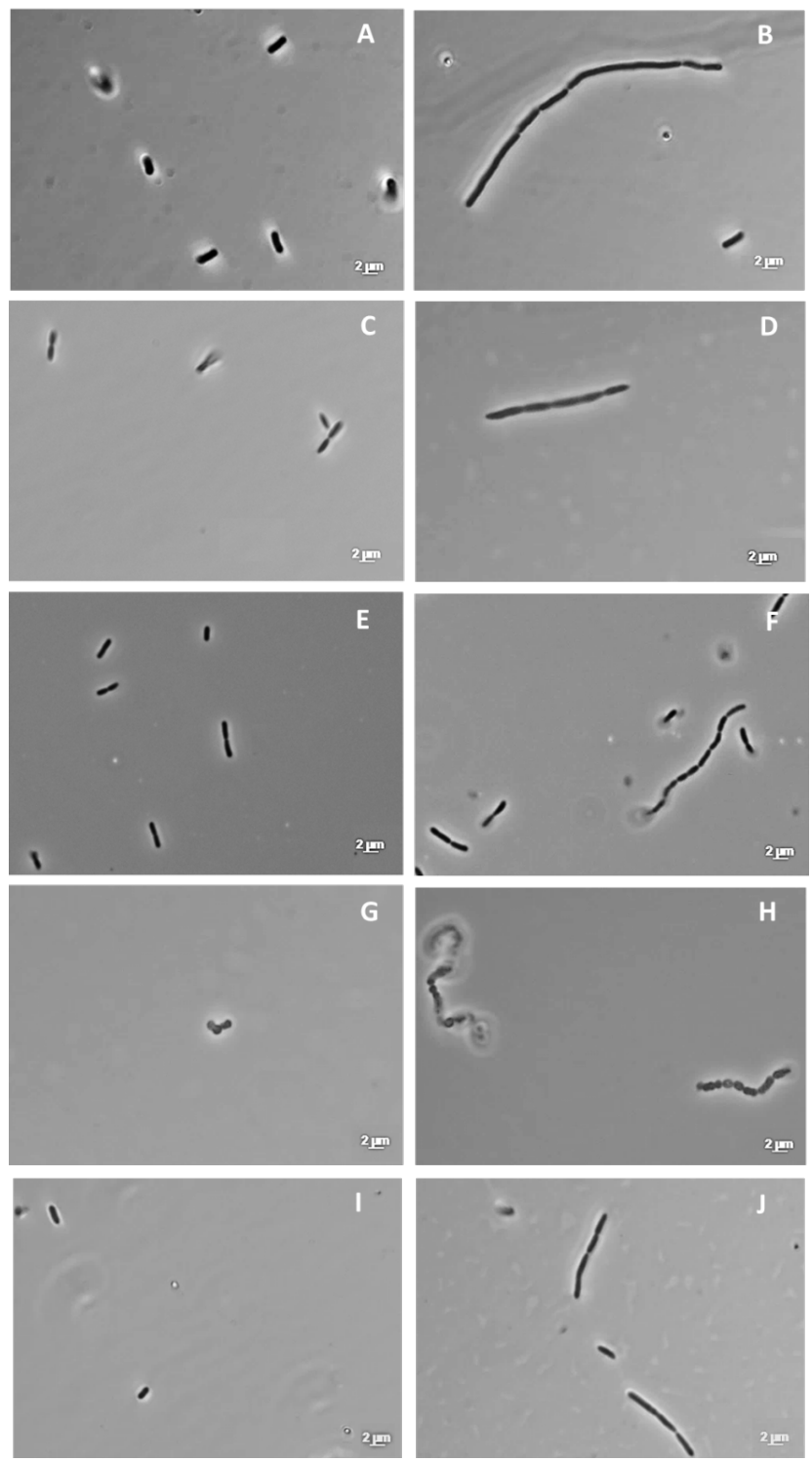

Figure 3. Light microscopy image of Buttiauxella sp. MASE-IM-9 (A, B), Clostridium sp. MASE-IM-4 (C, D), Halanaerobium sp. MASE-BB-1 (E, F), Trichococcus sp. MASE-IM-5 (G, H), Yersinia intermedia MASE-LG-1 (I, J) grown under standard cultivation conditions (first row, A, C, E, G, I) and cultivated in the presence of $1 \%$ wt Na-perchlorate (second row, B, D, F, H, J). 


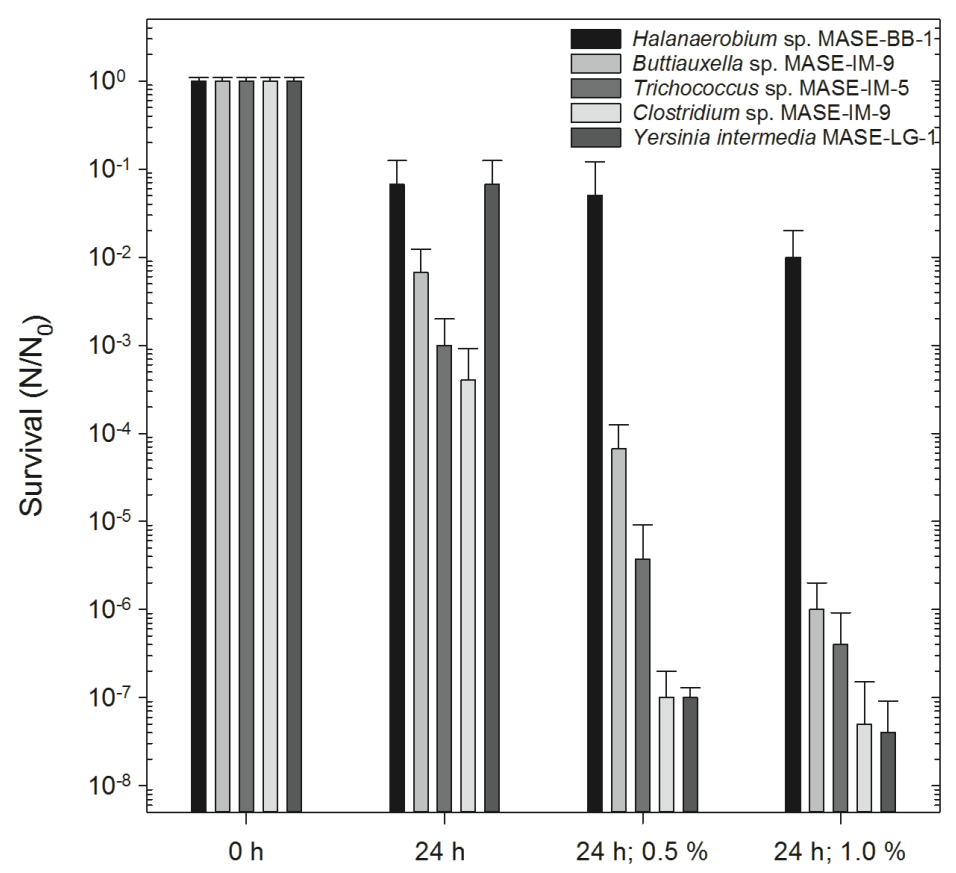

Time of desiccation [hours] and amount of Na-perchlorate [wt\%]

Figure 4. Influence of perchlorates on desiccation tolerance of MASE-strains (Halanaerobium sp. MASE-BB-1, Buttiauxella sp. MASE-IM-9, Trichococcus sp. MASE-IM-5, Clostridium sp. MASE-IM-4, Yersinia intermedia MASE-LG-1) under anoxic conditions. $\mathrm{N}_{0}$ : Viable cells without desiccation, $\mathrm{N}$ : Viable cells after desiccation in the absence or presence of perchlorates $(0.5 \mathrm{wt} \%$ or $1.0 \mathrm{wt} \%)$. Recovery was performed under standard cultivation conditions without perchlorate $(n=3)$. Error bars are representing the standard deviation.

effect was observed for Halanaerobium sp. MASE-BB-1, the highest effect was visible for Yersinia intermedia MASE-LG-1. In all cases, the reduction in the survival after desiccation did not reveal a substantial difference for both Mars relevant concentrations of $0.5 \mathrm{wt} \%$ and $1.0 \mathrm{wt} \%$ Na-perchlorate.

The combination of desiccation and ionizing radiation, led to additive effects of both stresses in all model organisms (Figure 5). Moreover, differential reactions to the stresses were observed: Clostridium sp. MASEIM-4 and Trichococcus sp. MASE-IM-5 showed enhanced radiation tolerance under stress in a dried state and both strains were able to multiply after application of ionizing radiation ( $3 \mathrm{kGy}$ ) in a desiccated state. In contrast, Buttiauxella sp. MASE-IM-9 and Trichococcus sp. MASE-IM-5 only showed additive effects after irradiation in a dried state. 


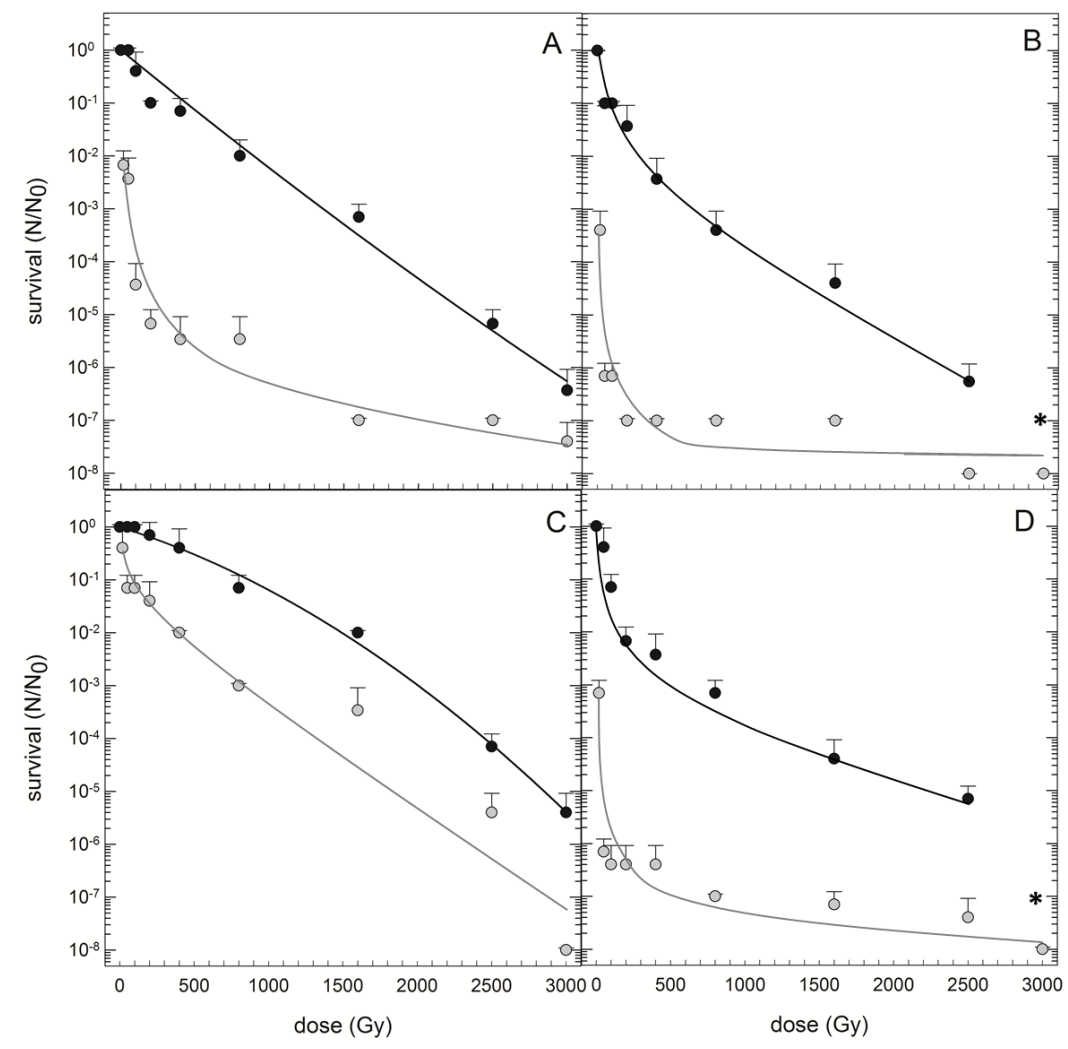

Figure 5. Survival of the MASE isolates (A: Buttiauxella sp. MASE-IM-9, B: Clostridium sp. MASE-IM-4, C: Halanaerobium sp. MASE-BB-1, D: Trichococcus sp. MASE-IM-5) after anoxic irradiation up to 3 kGy in liquid medium (black lines) and after the combination of anoxic desiccation (24 h) and subsequent exposure to ionizing radiation (up to $3 \mathrm{kGy}$ ) under anoxic conditions (grey lines). *: no viable cells detected. $\mathrm{N}_{0}$ : viable non-desiccated non-irradiated cells; $\mathrm{N}$ : viable cells after irradiation or after combined desiccation and irradiation $(n=3)$. Error bars are representing the standard deviation.

An additional decrease of the survival of about one to two orders of magnitude was observed after the cells were exposed to desiccating conditions in combination with Martian atmosphere and pressure $(2.7 \mathrm{vol} \%$ $\mathrm{N}_{2}, 1.6$ vol\% $\mathrm{Ar}, 0.15$ vol\% $\mathrm{O}_{2}$ in $\mathrm{CO}_{2}$ at a pressure of $10^{3} \mathrm{~Pa}$ ) (Figure 6). One exception was Clostridium sp. MASE-IM-4: the exposure to the Martian atmosphere enhanced the survival after desiccation after four weeks of storage (Figure 6B). In all other organisms, namely Buttiauxella sp. MASE-IM-9, Halanaerobium sp. MASE-BB-1, and Trichococcus sp. MASE-IM-5, additive effects of desiccation and the application of simulated Martian atmosphere were observed. 


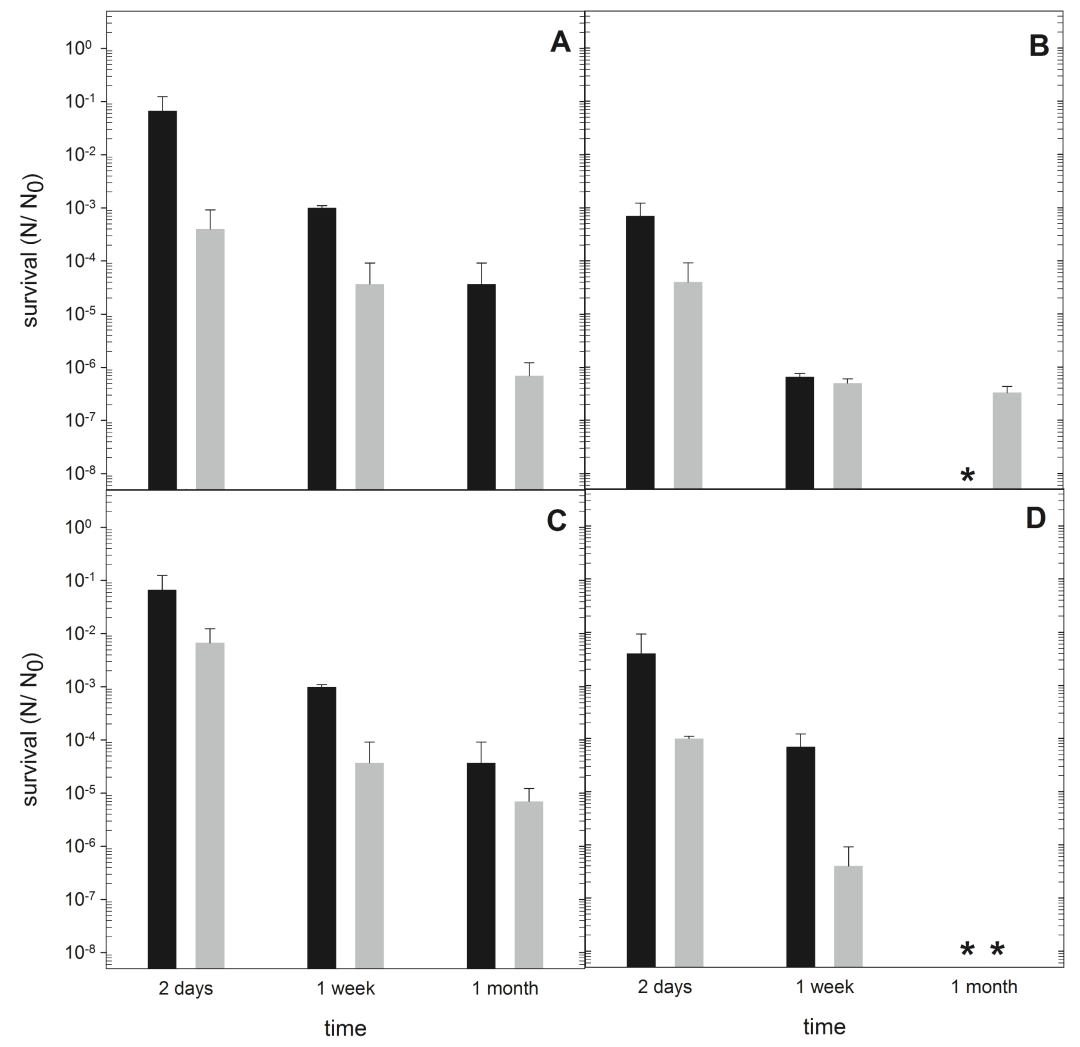

Figure 6. Survival of the MASE-strains (A: Buttiauxella sp. MASE-IM-9, B: Clostridium sp. MASE-IM-4, C: Halanaerobium sp. MASE-BB-1, D: Trichococcus sp. MASE-IM-5) after exposure to anoxic desiccation and Martian atmosphere. $\mathrm{N}_{0}$ : viable cells without desiccation and without exposure Martian atmosphere, $\mathrm{N}$ : viable cells after desiccation and exposure Martian atmosphere $(n=3)$. Error bars are representing the standard deviation. *: no viable cells detected. Black: Cells were desiccated under anoxic conditions. Grey: Cells were desiccated under anoxic conditions and exposed to Martian atmosphere (Mars gas at a pressure of $10^{-3} \mathrm{~Pa}$ ).

\section{Discussion}

In this study, we investigated the effects of individual and combined Marsrelevant stresses on (facultatively) anaerobic microorganisms. We focused on physical and chemical stress factors that are known to be prominent on the Martian surface and in the near-surface environment. They include the presence of perchlorates, desiccation, ionizing radiation and Martian atmospheric conditions. Each of the individual stress factors tested, i.e., desiccation, radiation, and perchlorates led to a reduction in survival rate of the organisms. For the investigated organisms it is not known whether they 
are able to metabolize perchlorates. Perchlorate concentrations similar to those studied here are not thought to exist in their natural environment. Therefore, it is not surprising that the presence of perchlorates played a major role in cell stress. Even short-term exposure of 15 minutes led to cell damaging effects. Comparison of the $D_{10}$-values with data from previous studies shows that the MASE-strains have a slightly lower tolerance to perchlorates than other model organisms, such as Escherichia coli and vegetative Bacillus subtilis cells (Beblo-Vranesevic et al., 2017b).

In this study the tolerance of different microorganisms to Martian relevant concentrations of perchlorates was tested $(0.5 \mathrm{wt} \%$ and $1.0 \mathrm{wt} \% \mathrm{Na}-$ perchlorate). The literature reports different tolerance levels amongst Bacteria and Archaea which do not metabolize perchlorates: one example of a sensitive organism is the acidophilic iron sulfur bacterium Acidithiobacillus ferrooxidans, possibly able to grow under Mars-like geochemical conditions but not able to multiply in the presence of $0.022 \mathrm{M}$ ( 0.5 wt\%) Mg-perchlorate (Bauermeister, 2012; Bauermeister et al., 2014). Halobacterium sp. NRC-1 a model halophilic archaeon cannot grow in the presence of $0.04 \mathrm{M} \mathrm{Na-perchlorate} \mathrm{(Laye} \mathrm{and} \mathrm{DasSarma,} \mathrm{2018).}$ Different methanogenic archaea (three Methanobacterium strains and two Methanosarcina strains) are also negatively influenced in their growth behavior at low concentrations (up to $0.01 \mathrm{M}$ ) of Na-perchlorate (Shcherbakova et al., 2015). It has been reported that several halotolerant strains show only slight alterations in their growth pattern in the presence of perchlorates: nearly all of the halotolerant isolates grew in the presence of 0.05 M Mg-perchlorate (Al Soudi et al., 2017). Comparable results were shown for halophilic bacteria, such as Alkalibacillus and Halomonas (Matsubara et al., 2017). Unfortunately, the absolute tolerance levels of organisms capable of metabolizing perchlorates, such as Dechloromonas hortensis and Aeropyrum pernix, are absent from the literature. These organisms were treated with perchlorate concentrations between $10 \mathrm{mM}$ and $50 \mathrm{mM}$ (Wolterink et al., 2005; Liebensteiner et al., 2015).

We also observed morphological changes, including filaments and cellchain formation associated with the presence of Na-perchlorate during growth. Such modification of size and shape has been observed earlier as a response to changes in the environmental conditions or to stress factors. Filamentation is one observed shape alteration that can be influenced by several factors such as nutrient deprivation, oxidative stress, DNA damage, exposure to antibiotics and temperatures shifts (Young, 2006; Justice et al., 2008; Perfumo et al., 2014). The observation of chain formation at $0.5 \mathrm{wt} \%$ Na-perchlorate in Buttiauxella sp. MASE-IM-9, Halanaerobium sp. MASEBB-1, Clostridium sp. MASE-IM-4, and Yersinia intermedia MASE-LG-1 and cluster-like structures in Trichococcus sp. MASE-IM-5 shows that Mars relevant concentrations of perchlorates are capable of causing microbial morphological anomalies. Morphological changes due to Na-perchlorate are also described for halophilic, thermophilic, and methanogenic 
microorganisms. Grown at the highest tolerated perchlorate concentrations, Halobacterium salinarum, Haloferax mediterranei, and Haloarcula marismortui were unusually swollen and deformed. For instance, Halomonas elongata cells appeared normal up to $0.2 \mathrm{M}$ Na-perchlorate, but in a medium with $0.4 \mathrm{M}$ Na-perchlorate, the cells had a thin and wrinkled appearance (Oren et al., 2014). The thermophilic bacterium Hydrogenothermus marinus tends to grow in chains in the presence of 0.3 M Na-perchlorate (Beblo-Vranesevic et al., 2017b). The methanogenic strain, Methanobacterium arcticum, shows other morphological changes and builds cyst-like cells in the presence of Mg-perchlorate (Shcherbakova et al., 2015). The reason for the morphological changes within the MASEstrains is not known. It is possible that the chain formation provides a survival advantage during cell damaging conditions such as has been hypothesized for biofilms (Cvitkovitch, 2004).

For experiments with combined stress factors with desiccation and radiation, desiccation and simulated Martian atmosphere, desiccation and perchlorates mainly additive effects could be shown. The negative influence of perchlorates on the cellular metabolism is also visible in the combination of perchlorate exposure and desiccation. Even low concentrations of perchlorates led to a reduction in survivability up to four orders of magnitude compared to desiccated cells without perchlorates. Interestingly, if Yersinia intermedia MASE-LG-1 cells were irradiated in the presence of different perchlorates in Martian relevant concentrations no influence on the survival after exposure to ionizing radiation was detected (Beblo-Vranesevic et al., 2017a). The combination of exposure to perchlorates and UV irradiation led to additive and even synergistic bactericidal effect for vegetative Bacillus subtilis cells (Wadsworth and Cockell, 2017).

An enhanced radiation tolerance was visible when the Clostridium $\mathrm{sp}$. MASE-IM-4 and Trichococcus sp. MASE-IM-5 were exposed to ionizing radiation in a dried form. This effect is also reported for some halophilic archaea (Leuko et al., 2015) and can be explained by the low abundance or absence of intra- and extracellular water within the desiccated samples. Consequently, radiolysis cannot occur due to exposure to ionizing radiation. A lower concentration of reactive oxygen species can be assumed. Absorption effects of the ingredients of the medium can be excluded since ionizing radiation penetrates through the (in-) organic residues of the medium. The exposure of dried cells to Martian atmosphere had no effect on the survival; i.e. once the cells survived the first desiccation step, they were stable with respect to additional desiccation in Martian atmosphere. These data are in accordance to data from literature: if Deinococcus radiodurans is exposed to Martian atmosphere (7 days) the survival rate was reduced less than one order of magnitude (Pogoda de la Vega et al., 2007). 


\section{Conclusion}

The selected organisms obtained from extreme anoxic analogue environments on Earth were shown to possess not only a high tolerance against the environmental stresses that occur in their normal habitat, but also exhibit a substantial tolerance to individual and combined Mars relevant stress factors, i.e. desiccation, Martian atmosphere and pressure, ionizing radiation, and the presence of perchlorates. The observed effects of combined stress factors were found to be additive in the case of Buttiauxella sp. MASE-IM-9 and Halanaerobium sp. MASE-BB-1, and synergistic in the case of Clostridium sp. MASE-IM-4 and Trichococcus sp. MASE-IM-5. The desiccation step seems to give a relative advantage to cells to cope with other stress factors which provides constraints for the search for live on Mars. Moreover, these MASE strains were even able to grow in the presence of Martian relevant concentrations of Na-perchlorate under anoxic conditions. Our data show that survival in Martian environments, i.e. Martian brines, is in principle possible for some organisms. This work advances our understanding of the limits of survival in Mars-relevant conditions.

\section{References}

Al Soudi, AF., Farhat, O., Chen, F., Clark, BC., and Schneegurt, MA. (2017). Bacterial growth tolerance to concentrations of chlorate and perchlorate salts relevant to Mars. Int. J. Astrobiol. 16, 229-235.

Archer, PD. Jr., Sutter, B., Ming, DW., McKay, CP., Navarro-Gonzalez, R., Franz, HB., McAdam A., Mahaffy PR., and the MSL Science Team. (2013). Possible detection of perchlorates by evolved gas analysis of rocknest soils: global implications. In: Proceedings of the 44th Lunar and Planetary Science Conference Abstracts (Houston, TX: Lunar and Planetary Institute).

Bauermeister, A. (2012). Characterization of stress tolerance and metabolic capabilities of acidophilic iron-sulfur-transforming bacteria and their relevance to Mars. Doctoral dissertation, University of Duisburg-Essen, Duisburg.

Bauermeister, A., Rettberg, P., and Flemming, HC. (2014). Growth of the acidophilic iron-sulfur bacterium Acidithiobacillus ferrooxidans under Mars like geochemical conditions. Planet. Space Sci. 98, 205-215.

Beblo, K., Rabbow, E., Rachel, R., Huber, H., and Rettberg, P. (2009). Tolerance of thermophilic and hyperthermophilic microorganisms to desiccation. Extremophiles. 13, 521-531.

Beblo, K., Douki, T., Schmalz, G., Rachel, R., Wirth, R., Huber, H., Reitz, G., and Rettberg, P. (2011). Survival of thermophilic and hyperthermophilic microorganisms after exposure to UV-C, ionizing radiation and desiccation. Arch. Microbiol. 193, 797-809.

Beblo-Vranesevic, K., Bohmeier, M., Perras, AK., Petra Schwendner, P., Rabbow, E., Moissl-Eichinger, C., Charles S. Cockell, CS., Pukall, R., Vannier, P., Marteinsson, VT., Monaghan, EP., Ehrenfreund, P., GarciaDescalzo, L., Gómez, F., Malki, M., Amils, R., Gaboyer, F., Westall, F., 
Cabezas, P., Walter, N., and Rettberg, P. (2017a). The responses of an anaerobic microorganism, Yersinia intermedia MASE-LG-1 to individual and combined simulated Martian stresses. PloS One. 12, e0185178.

Beblo-Vranesevic, K., Huber, H., and Rettberg, P. (2017b) High tolerance of Hydrogenothermus marinus to sodium perchlorate. Front.Microbiol. 8, 1369.

Carrier, BL., and Kounaves, SP. (2015). The origins of perchlorate in the Martian soil. Geophys. Res. Lett. 42, 3739-3745.

Catling, DC., Claire, MW., Zahnle, KJ., Quinn, RC., Clark, BC., Hecht, MH., and Kounaves, S. (2010). Atmospheric origins of perchlorate on Mars and in the Atacama. J. Geophys. Res. Planet. 115, E00E11.

Cockell, CS., Bush, T., Bryce, C., Direito, S., Fox-Powell, M., Harrison, JP., Lammer, H., Landenmark, H., Martin-Torres, J., Nicholson, N., Noack, L., O'Malley-James, J., Payler, SJ., Rushby, A., Samuels, T., Schwendner, P., Wadsworth, J., and Zorzano, MP. (2016). Habitability: a review. Astrobiology. 16, 89-117.

Cockell, CS., Schwendner, P., Perras, A., Rettberg, P., Beblo-Vranesevic, K., Bohmeier, M., Rabbow, E., Moissl-Eichinger, C., Wink, L., Marteinsson, V., Vannier, P., Gomez, F., Garcia-Descalzo, L., Ehrenfreund, P., Monaghan, E.P., Westall, F., Gaboyer, F., Amils, R., Malki, M., Pukall, R., Cabezas, P. and Walter, N. (2017). Anaerobic microorganisms in astrobiological analogue environments: from field site to culture collection. Int. J. Astrobiol. 1-15.

Cvitkovitch, D. (2004). Genetic exchange in bioflms. In: Ghannoum, M., O'Toole, G. (ed). Microbial Bioflms. Washington, DC, ASM Press, 192-205.

Dartnell, LR., Desorgher, L., Ward, JM., and Coates, AJ. (2007). Modelling the surface and subsurface martian radiation environment: implications for astrobiology. Geophys. Res. Let. 34.

Eigenbrode, JL., Summons, RE., Steele, A., Freissinet, C., Millan, M., Navarro-González, R., Sutter, B., McAdam, AC., Franz, HB., Glavin, DP., Archer, PD., Mahaffy, PR., Conrad PG., Hurowitz JA., Grotzinger JP., Gupta S., Ming DW., Sumner DY., Szopa C., Malespin C., Buch A., and Coll, P. (2018). Organic matter preserved in 3-billion-year-old mudstones at Gale crater, Mars. Science. 360, 1096-1101.

Fox-Powell, MG., Hallsworth, JE., Cousins, CR., and Cockell, CS. (2016). lonic strength is a barrier to the habitability of Mars. Astrobiology. 16, 427.-442.

Franson, MAH. (ed.). (1985). Standard methods for the examination of water and wastewater. In: American Public Health Association, 16 ${ }^{\text {th }}$ edition, Washington DC.

Glavin, DP., Freissinet, C., Miller, KE., Eigenbrode, JL., Brunner, AE., Buch, A., Sutter, B., Archer, PD. Jr., Atreya, SK., Brinckerhoff, WB., Cabane, M., Coll, P., Conrad, PG., Coscia, D., Dworkin, JP., Franz, HB., Grotzinger, JP., Leshin, LA., Martin, MG., McKay, C., Ming, DW., Navarro-González, R., Pavlov, A., Steele, A., Summons, RE., Szopa, C., Teinturier, S., and Mahaffy, PR. (2013). Evidence for perchlorates and the origin of 
chlorinated hydrocarbons detected by SAM at the Rocknest aeolian deposit in Gale Crater. J. Geophys. Res. Planets. 118, 1955-1973.

Gough, RV., Chevrier, VF., Baustian, KJ., Wise, ME., and Tolbert, MA. (2011). Laboratory studies of perchlorate phase transitions: support for metastable aqueous perchlorate solutions on Mars. Earth Planet. Sci. Lett. 312, 371-377.

Gu, W., Li, Y., Tang, M., Jia, X., Ding, X., Bi, X., and Wang, X. (2017).Water uptake and hygroscopicity of perchlorates and implications for the existence of liquid water in some hyperarid environments. RSC Advances. 7, 46866-46873.

Hassler, DM., Zeitlin, C., Wimmer-Schweingruber, RF., Ehresmann, B., Rafkin, S., Eigenbrode, JL., Brinza, DE., Weigle, G., Böttcher, S., Böhm, E., Burmeister, S., Guo, J., Köhler, J., Martin, C., Reitz, G., Cucinotta, FA., Kim, M-H., Grinspoon, D., Bullock, MA., Posner, A., Gómez-Elvira, J., Vasavada, A., Grotzinger, JP., and MSL Science Team. (2014). Mars' surface radiation environment measured with the Mars Science Laboratory's Curiosity rover. Science. 343, 1244797.

Hecht, MH., Kounaves, SP., Quinn, RC., West, SJ., Young, SM., Ming, DW., Catling, DC., Clark, BC., Boynton, WV., Hoffman, J., DeFlores, LP., Gospodinova, K., ,Kapit, J., and Smith, PH. (2009). Detection of perchlorate and the soluble chemistry of Martian soil at the Phoenix lander site. Science. 325, 64-67.

Horneck, G. (2000). The microbial world and the case for Mars. Planet. Space Sci. 48, 1053-1063.

Jakosky, BM., and Phillips, RJ. (2001). Mars' volatile and climate history. Nature. 412, 237-244.

Justice, SS., Hunstad, DA., Cegelski, L., and Hultgren, SJ. (2008). Morphological plasticity as a bacterial survival strategy. Nat. Rev. Microbiol. 6, 162-168.

Kim, YS., Wo, KP., Maity, S., Atreya, SK., and Kaiser, RI. (2013). Radiation induced formation of chlorine oxides and their potential role in the origin of Martian perchlorates. J. Am. Chem. Soc. 135, 4910-4913.

Kounaves, SP., Chaniotakis, NA., Chevrier, VF., Carrier, BL., Folds, KE., Hansen, VM., McElhoney, KM., O'Neil, GD., and Weber, AW. (2014). Identification of the perchlorate parent salts at the Phoenix Mars landing site and possible implications. Icarus. 232, 226-231.

Laye,VJ., and DasSarma, S. (2018). An Antarctic Extreme Halophile and Its Polyextremophilic Enzyme: Effects of Perchlorate Salts. Astrobiology. 18, 412-418.

Leuko, S., Domingos, C., Parpart, A., Reitz, G., and Rettberg, P. (2015). The survival and resistance of Halobacterium salinarum NRC-1, Halococcus hamelinensis, and Halococcus morrhuae to simulated outer space solar radiation. Astrobiology. 15, 987-997.

Liebensteiner, MG., Pinkse, MW., Nijsse, B., Verhaert, PD., Tsesmetzis, N., Stams, AJ., Lomans, BP. (2015). Perchlorate and chlorate reduction by the Crenarchaeon Aeropyrum pernix and two thermophilic Firmicutes. Environ. Microbiol. Rep. 7, 936-945. 
Matsubara, T., Fujishima, K., Saltikov, CW., Nakamura, S., and Rothschild, LJ. (2017). Earth analogues for past and future life on Mars: isolation of perchlorate resistant halophiles from Big Soda Lake. Int. J. Astrobiol. 16, 218-228.

Matthiä, D., Ehresmann, B., Lohf, H., Köhler, J., Zeitlin, C., Appel, J., Sato, T., Slaba, T., Martin, C., Berger, T., Boehm, E., Boettcher, S., Brinza, DE., Burmeister, S., Guo, J., Hassler, DM,, Posner, A., Rafkin, SCR., Reitz, G., Wilson, JW., and Wimmer-Schweingruber RF. (2016). The Martian surface radiation environment-a comparison of models and MSL/RAD measurements. J. Space Weather Space Clim. 6, A13.

Martín-Torres, FJ., Zorzano, MP., Valentín-Serrano, P., Harri, AM., Genzer, M., Kemppinen, O., Rivera-Valentin, EG., Jun, I., Wray, J., Madsen, MB., Goetz, W., McEwen, AS., Hardgrove, C., Renno, N., Chevrier, VF., Mischna, M., Navarro-González, R., Martínez-Frías, J., Conrad, P., McConnochie, T., Cockell, C., Berger, G., Vasavada, AR., Sumner, D., and Vaniman, D. (2015). Transient liquid water and water activity at Gale crater on Mars. Nat. Geosci. 8, 357-361.

McEwen, AS., Ojha, L., Dundas, CM., Mattson, SS., Byrne, S., Wray, JJ., Cull SC., Murchie SL., Thomas N., and Gulick VC. (2011). Seasonal flows on warm Martian slopes. Science. 333, 740-743.

Ojha, L., Wilhelm, MB., Murchie, SL., McEwen, AS., Wray, JJ., Hanley, J., Massé M., and Chojnacki M. (2015). Spectral evidence for hydrated salts in recurring slope lineae on Mars. Nat. Geosci. 8, 829-832.

Oren, A., Bardavid, RE., and Mana, L. (2014). Perchlorate and halophilic prokaryotes: implications for possible halophilic life on Mars. Extremophiles. 18, 75-80.

Orosei, R., Lauro, SE., Pettinelli E., Cicchetti, A., Coradini, M., Cosciotti, B., Di Paolo BF., Flamini, E., Mattei, E., Pajola, M., Soldovieri, F., Cartacci, M., Cassenti, F., Frigeri, A., Giuppi, S., Martufi, R., Masdea, A., Mitri, G., Nenna, C., Noschese, R., Restano, M., Seu, R. (2018) Radar evidence of subglacial liquid water on Mars. Science. eaar7268.

Perfumo, A., Elsaesser, A., Littmann, S., Foster, RA., Kuypers, MM., Cockell, CS., and Kminek, G. (2014). Epifluorescence, SEM, TEM and nanoSIMS image analysis of the cold phenotype of Clostridium psychrophilum at subzero temperatures. FEMS Microbiol. Ecol. 90, 869-882.

Pogoda de La Vega, U., Rettberg, P., and Reitz, G. (2007). Simulation of the environmental climate conditions on Martian surface and its effect on Deinococcus radiodurans. Adv. Space Res. 40, 1672-1677.

Schubert, G., Russell, CT., and Moore, WB. (2000). Geophysics: Timing of the Martian dynamo. Nature. 408, 666.

Schuttlefield, JD., Sambur, JB., Gelwicks, M., Eggleston, CM., and Parkinson, BA. (2011). Photooxidation of chloride by oxide minerals: implications for perchlorate on Mars. J. Am. Chem. Soc. 133, 17521-17523. 
Shcherbakova, V., Oshurkova, V., and Yoshimura, Y. (2015). The effects of perchlorates on the permafrost methanogens: implication for autotrophic life on Mars. Microorganisms. 3, 518-534.

Toner, JD., and Catling, DC. (2016). Water activities of $\mathrm{NaClO}_{4}, \mathrm{Ca}\left(\mathrm{ClO}_{4}\right)_{2}$, and $\mathrm{Mg}\left(\mathrm{ClO}_{4}\right)_{2}$ brines from experimental heat capacities: water activity > 0.6 below 200K. Geochim. Cosmochim. Acta. 181, 164-174.

Tosca, NJ., Knoll, AH., and McLennan, SM. (2008). Water activity and the challenge for life on early Mars. Science. 320, 1204-1207.

Wadsworth, J., and Cockell, CS. (2017). Perchlorates on Mars enhance the bacteriocidal effects of UV light. Scientific reports. 7, 4662.

Westall, F., Loizeau, D., Foucher, F., Bost, N., Betrand, M., Vago, J., and Kminek, G. (2013). Habitability on Mars from a microbial point of view. Astrobiology. 13, 887-897.

Wolterink, A., Kim, S., Muusse, M., Kim, IS., Roholl, PJ., van Ginkel, CG., Stams, AJ., Kengen, SW. (2005). Dechloromonas hortensis sp. nov. and strain ASK-1, two novel (per)chlorate-reducing bacteria, and taxonomic description of strain GR-1. Int. J. Syst. Evol. Microbiol. 55, 2063-2068.

Young, KD. (2006). The selective value of bacterial shape. Microbiol. Mol. Biol. Rev. 70, 660-703. 
caister.com/astro 